\title{
Measuring collaborative stakeholder influence and open
} budget actions

Welles Matias de Abreu'

Ricardo Corrêa Gomes ${ }^{1}$

1 Universidade de Brasília, Brasília / DF — Brazil

Collaborative stakeholder influence and open budget actions are important elements in governance in order to promote social development (Ansell and Gash, 2008). However, it is important to clarify how to measure these supposedly independent elements. The aim of the article is to identify ways to measure the influence of collaborative stakeholders and open budget actions. The methodological aspects focus on data collection through interviews and content analysis. The conclusion is that the number of civil society organizations and the presence of social councils and their operational components are relevant measures of collaborative stakeholder influence and open budget actions, respectively. In addition, this article highlights the relevance of integrating collaborative stakeholder influences with open budget actions. Finally, a research agenda is proposed.

Keywords: collaborative stakeholder; open budget; governance outcomes; measurement forms; social development.

\section{Medindo o nível da influência colaborativa dos stakeholders e das ações de orçamento aberto}

A influência colaborativa dos stakeholders e as ações de orçamento aberto são elementos importantes na Governança para promover o desenvolvimento social (Ansell e Gash, 2008). No entanto, um ponto que precisa ser esclarecido é como medir esses elementos supostamente independentes. Nesse sentido, o objetivo deste artigo é identificar maneiras de medir a influência colaborativa dos stakeholders e ações de orçamento aberto. Os aspectos metodológicos centram-se na coleta de dados por meio de entrevistas e na análise de conteúdo para identificação dos resultados. Conclui-se que o número de organizações da sociedade civil e a presença de iniciativas no âmbito dos conselhos sociais são formas de medir a influência colaborativa dos stakeholders e nas ações de orçamento aberto, respectivamente. Além disso, este trabalho destaca a importância de se integrar a influência colaborativa dos stakeholders e as ações de orçamentos abertos. Por fim, propõe-se uma agenda de pesquisa.

Palavras-chave: stakeholders colaborativos; orçamento aberto; resultados de governança; formas de medição; desenvolvimento social.

\section{Medición de la influencia colaborativa de las partes interesadas y las medidas de presupuesto abierto}

La influencia colaborativa de las partes interesadas y las acciones de presupuesto abierto son elementos importantes en la gobernanza para promover el desarrollo social (Ansell y Gash, 2008). Un punto que necesita ser aclarado es cómo medir estos elementos supuestamente independientes. El objetivo del documento es identificar maneras de medir la influencia de las partes interesadas de colaboración y acciones de presupuesto abierto. Los aspectos metodológicos se centran en la recogida de datos mediante entrevistas y análisis de contenido para la identificación de resultados. Concluimos que el número de organizaciones de la sociedad civil y la presencia de los consejos sociales y sus componentes operacionales son medidas relevantes de influencia colaborativa de las partes interesadas y acciones de presupuesto abierto, respectivamente. Además, este documento destaca la relevancia para integrar las influencias colaborativas de las partes interesadas con las acciones de presupuesto abierto. Finalmente, propone una agenda de investigación.

Palabras claves: interesados en colaboración; presupuesto abierto; resultados de la gobernanza; formas de medición; Desarrollo Social. 


\section{INTRODUCTION}

Social development improves social welfare and individual quality of life by introducing institutional changes to make society more equitable and inclusive for all members (Davis, 2004). Governments that prioritise people in decision-making processes give them the opportunity to participate in the promotion of public policies (Department for International Development, 2006; World Bank, 2014).

The open budget approach (OBA) relates to transparency, participation, and accountability (Khagram et al., 2013; Ling and Roberts, 2014). The literature on governance suggests that open budget initiatives support improvements to social development (Khagram et al., 2013; Ling and Roberts, 2014; De Renzio and Wehner, 2017). For example, Bangladesh implemented a project between 2000 and 2006 funded by United Nations Development Programme in which government collaborated with civil society organisations to achieve OBA (Sarker and Hassan, 2010), focusing on promoting more equitable distribution of resources, reducing of corruption, and improving of social conditions.

The adoption of a collaborative perspective in the decision-making processes of managing government resources is strategic because it improves the performance of public organisations in conjunction with robust governance initiatives, such as the OBA to governance (Ling and Roberts, 2014). In this context, the management style supports the performance of public organisations (O'toole and Meier, 1999).

The collaborative style of governance engages people constructively across the boundaries of public agencies, using strategies involving high levels of transparency and accountability (Emerson et al., 2012). Non-governmental and governmental stakeholders work collectively to establish rules for the provision of public goods (Ansell and Gash, 2008). In this process, leadership is crucial for establishing and maintaining clear rules in order to build trust and to support negotiations for mutual benefit (Bovaird, 2005; Ansell and Gash, 2008; Emerson et al., 2012; Khagram et al., 2013).

Not only does the OBA achieve excellence by aggregating preferences to solve collective problems in a democratic environment, but it also satisfies the desires and aspirations of a society driven by collaborative stakeholder influence (CSI) (Abreu and Gomes, 2013). The literature on open budgets suggests that the combination of CSI and OBA supports effective governance. For instance, according to Ansell and Gash (2018), the adoption of collaborative platforms promotes synergy between CSI and OBA, based on the production of positive public value-creating to achieve governance results. Nevertheless, it is not clear how to measure these core open budget elements.

The aim of the paper is to identify ways to measure levels of CSI and OBA as determinants of social development. We hope to provide empirical results on the OBA and to stimulate research on financial sustainability, to reduce poverty and induce economically equitable growth, and ultimately to achieve sustainable progress (Siau and Long, 2006; Justice and Mcnutt, 2013).

Empirical measurement of CSI and OBA will support new studies that use qualitative and quantitative methods. Because this is innovative work from the new open budget perspective, we expect this paper to contribute to extending theory in this field. We hope that governments will use the results presented in this paper to improve their social impact. 
According to Ling and Roberts (2014), research into effective approaches to measuring open budget elements can help to achieve social development. Based on this proposed focus for study, we produce new empirical evidence suggesting that the number of civil society organisations (for example, those that are identified in the Brazilian IBGE Fasfil Survey) determines the level of CSI, while the presence of social councils, open data, participatory budgeting, and government answerability, indicate the level of OBA.

The paper is structured as follows. In the next section, we review the literature. The methodological aspects of the research follows. We present and discuss the results, grouped by the measurement forms, complementary issues, and further perspectives of CSI and OBA. Finally, we highlight the main theoretical and practical contributions of the paper for depicting collaborative stakeholder influences and open budget actions as sources of social development.

\section{LITERATURE REVIEW}

Greater discretion, responsiveness, and openness are in evidence in the new public governance perspective, which is, according to the literature, based on citizens' engagement, focused on the public interest, and structured in an environment of democratic citizenship (Denhardt and Denhardt, 2007:25-29). From the governance perspective, the management of the public budget ought to be collaborative, stimulating interactions between non-governmental and governmental stakeholders in a network of public, civic and business institutions (Bovaird, 2005).

Historically, the ancient Athenians decided on public budgetary issues by negotiating a collective consensus before social policies were executed (Tanaka, 2007). In spite of that precedent, governments have to a large extent maintained a good deal of secrecy in their budgetary allocations, involving only a few agents in their decision-making processes (Abreu and Gomes, 2013; Khagram et al., 2013). Contemporary transitions to democratic regimes have been seen as opening a window of opportunity for more open budgets and collaborative initiatives, stimulating new reflections on social progress (Kasymova and Schachter, 2014; Ling and Roberts, 2014).

The OBA increases collaboration in the arena of the public budget whatever the stage of the budgetary process - drafting, approval, execution, and auditing (Gaventa and Mcgee, 2013; Ling and Roberts, 2014). The collaboration of stakeholders is likely to promote decisions about governance that include social commitment in the budgetary process. In this arena, disputes and tensions are common (Department for International Development, 2006; World Bank, 2014, 2006; Burge, 2010).

In the next section, we present the theoretical approaches to collaborative stakeholders and open budgets, and the theoretical considerations to support this study.

\subsection{COLLABORATIVE STAKEHOLDERS}

According to Koontz (2005:460), "collaboration is characterised by diverse stakeholders working together to resolve a conflict or develop and advance a shared vision." The relationships between collaborative stakeholders are based on public and organisational values, and collective social rules support collective gains (Freeman, 1984). 
The collaborative stakeholders are those who influence the strategic management process to respond to causes that are important to the community (Keijzers, 2003), contributing with innovatory products and services and preserving the shared environment (Svendsen, 1998). Moreover, they can support government actions and help to deliver social policies (Gomes and Gomes, 2008; Gomes et al., 2010).

Freeman (1984:46) states that, "[a] stakeholder in an organisation is (by definition) any group or individual who can affect or is affected by the achievement of the organisation's objectives." In general, a stakeholder is the one who has power, urgency, and legitimacy, based on demands and expectations (Mitchell et al., 1997).

The complexity of stakeholders' political and social networks explains why it is so difficult to calculate collective results (Abreu and Gomes, 2013). According to Streeck and Thelen (2005), an institution's development, transformation, maintenance, and division may be explained by the actions of stakeholders.

Depending on the type of stakeholder the institution is involved with, changes happen in different ways (Gomes and Gomes, 2008). Frequently, stakeholders that are more dependent on a given organisation demonstrate greater commitment to cooperation (Freeman, 1984).

The potential for stakeholder cooperation is particularly relevant since it may support collaborative efforts involving an organisation and its stakeholders, which may result in better management of the business setting (Savage et al., 1991). Stakeholder cooperation is often ignored because the analysis requires a sophisticated understanding of the types and magnitude of stakeholder influence (Gomes and Gomes, 2008).

Collaborative Stakeholder Influences (CSI) have the potential to gather strength from those who act in support of the leadership in order to produce mutual gain among public agencies and non-state stakeholders (Ansell and Gash, 2008; Adadevoh, 2014). Public agencies have a distinctive leadership role in collaborative governance (Ansell and Gash, 2008). It is important for collaborative stakeholder leadership to engage with public agencies and non-state stakeholders in order to produce a consensus through the public policy decision-making process (Khagram and Ali, 2008).

Emerson and collaborators (2012:14) argue that, in collaboration governance, "quality interaction through principled engagement will help foster trust, mutual understanding, internal legitimacy, and shared commitment, thereby generating and sustaining shared motivation". It is important that government actions are carried out in a communicative manner (in a collective, collaborative and cooperative environment) seeking to satisfy social needs (Khagram and Ali, 2008; Khagram et al., 2013; Ling and Roberts, 2014). Hence, collaborative stakeholders ought to facilitate communication focused on the potential influence on government decision-making processes.

A Korean case study showed that non-governmental stakeholders (of the Citizens Coalition for Economic Justice) influenced collaborative budgetary commitments and promoted social improvements (You and Lee, 2013). But the literature still lacks ways to measuring CSI. A starting point to help in CSI measurement is provided by Gomes and Gomes (2008:265): "a stakeholder can be people, categories of people - such as employees, managers, suppliers, owners and customers (service users of public organisations) - and organisations." The stakeholder influence should be 
focused on the identification of who has the power and interest upon government decision-making process (Gomes et al., 2010).

\subsection{OPEN BUDGETS}

Jinguang and Xianyong (2011:72) state that, "Open budget means that the whole course of the annual financial revenue and expenditure plan, from its working out and its examining and approval to its executing, should be disclosed to the public in an appropriate manner." The Open Budget Actions (OBA) involve initiatives that achieve government transparency, participation, and accountability (Ling and Roberts, 2014).

The adoption of OBA is subject to an ongoing debate about who represents civil society, and ranging from direct democracy to indirect delegate models (Mansuri and Rao, 2004; Ling and Roberts, 2014). The literature suggests that increasing use of the OBA improves government performance related to social gains (Siau and Long, 2006; Khagram et al., 2013; Ling and Roberts, 2014; De Renzio and Wehner, 2017). The existence of logical links, as well as ongoing loops, emphasises that open budgeting in linked with actions in a mutually reinforcing and integrated model (Khagram et al., 2013; Ling and Roberts, 2014).

The Open Budget Index (OBI) "is a useful addition to existing tools, thanks to its rigorous methodology, independence, and comparability" (De Renzio and Masud, 2011:614). According to Renzio and collaborators (2009), there is statistical evidence of a positive relationship between OBI and the Human Development Index (HDI) in resource-dependent countries.

However, the OBI focuses mainly on transparency. Therefore, an index to measure transparency, participation and accountability has yet to be developed. Participation and accountability have often been omitted from open budget actions. Hence, measuring OBA is the starting point for developing a more sophisticated approach.

The transparency, participation, and accountability are required actions in a process of social gaining in order to promote the disclose information, the public engagement, and the accountable government (Abreu, 2013; Abreu and Gomes, 2016). In this process, it is expected that transparency comes about first, followed by participation, and then accountability (Khagram et al., 2013). Take note that CSI participates in the government decision-making process in order to influence resources allocation by the OBA, for instance, from collaborative platforms (Ansell and Gash, 2018).

Transparency means making information publicly available through relevant laws, regulations and other policies, notifying the interested parties about relevant laws and regulations, and ensuring that laws and regulations are administered in a uniform, impartial and reasonable manner (Nowak, 2000; Meijer, 2009, 2013). In the same vein, budgetary transparency involves full disclosure of all relevant fiscal information in a timely and systematic manner (Oecd, 2002).

Participation creates incentives to articulate and aggregate citizens' interests, to provide channels for the recruitment of leaders, to adjudicate disputes between conflicting interests, and to engage citizens in the government decision-making process by providing links between the rulers and the ruled, policymakers and citizens (Fung and Wright, 2003; Shah, 2007; Boulding and Wampler, 
2010). Participatory budgeting is seen as a type of political empowerment and an incentive for citizens' engagement, and it also strengthens inclusive governance (Brown, 2002; Armstrong, 2006) by giving marginalized and excluded people the right to have their voices heard and to influence public decision making (Yilmaz et al., 2010; Wampler, 2012; Gaventa and Mcgee, 2013; Kasymova and Schachter, 2014). According to Fung (2006:72), the "participation mechanisms that employ random selection or even lay stakeholder involvement may also enhance political equality if they are properly implemented".

Finally, accountability is the responsibility and responsiveness exercised by state authorities during the period between political elections in democracies. It involves citizens' ability to hold those who exercise power accountable for their actions (Goetz and Jenkins, 2001; Ackerman, 2004; Friis-Hansen and Cold-Ravnkilde, 2013). Accountability is very complex (Tisné, 2010), and is central to public and social approaches linked with transparency and participation initiatives (Yilmaz et al., 2010). Procedures for public hearings to investigate spending, public audits and an independent judiciary make it possible to achieve budgetary accountability (Alt and Lowry, 2010).

From the governance perspective, the CSI and the OBA are directly associated with collaboration behaviour (De Almeida, 2015). The OBA should support the construction of the social consensus in public policy settings. Moreover, this process is very important to democracy strengthening, focusing on inclusive initiatives. The classic democracy considers that OBA activates CSI with equity and reliable opportunities to cooperate with social policy sets (Emerson et al., 2012; Khagram et al., 2013; Ansell and Gash, 2018).

\section{METHODOLOGICAL ASPECTS}

The purpose is to identify how to measure the open budgets' core elements (CSI and OBA) in order to figure out the importance of transparency, participation, and accountability on making a society more developed and fair. Evidence based on policy and practice can produce a better understanding of "what works with whom and in what circumstances" (Boaz and Nutley, 2003:332).

Following the interpretative strategy put forward by Siverman (2010), the methodological aspects are designed to be executed using qualitative methods. Comparative analyses are required to identify pragmatic evidence. Therefore, the data were collected from open questions in interviews conducted by Brazilian professionals who have expertise in the area of public budgeting (Lee and Lings, 2008; Creswell, 2013).

This paper focuses on the identification of performance indicators for measuring OBA and CSI in the Brazilian governance structure. Brazil is taken as a case study in this paper because, in the 2012 Open Budget Survey (IBP, 2014), it was the twelfth in a world sample of one hundred countries. In the same survey, Brazil was also at the leading position in Latin America.

From November 2015 to February 2016, were conducted 15 open-end interviews (three for each group of respondents) from National Congress consultants (NCC), government finance analysts (GFA), social government executives (SGE), public budget researchers (PBR), and civil 
society organisation's (CSO) leaders. Finally, were carried out content analysis of the data to describe open budget's core elements, which may be used at all levels of government (Bardin, 1977; Silverman, 2010).

The NCC, GFA and SGE interviewed were all federal and local budgetary specialists. These groups focus on the legislative budgetary process, executive control of finance, and social policy execution. The selection of the respondents from each group considered their professional experiences in open budgeting processes, for instance, related to the production of initiatives on open data systems, citizen budget reports, public policy councils, and public hearings.

In this context, it was always given preference to interview the chiefs of departments, from the legislative and executive government organizations, that take care of Brazilian OBA. Considering the existence of specific areas in finance secretariats that execute initiatives related to open budgeting, it was possible to select respondents from budget, treasure, and audit bureaus, as well as respondents from health and education ministries associated to social policy execution.

The public budget researchers interviewed were employees of government economic and statistical entities linked to the Budget Ministry, and an accounting professor at the University of Brasilia. The leaders of civil society organisations were from the International Budget Partnership, the Institute for Socioeconomic Studies, and the Open Accounts, who are cited by Zuccolotto (2014) as watchdogs that act in Brazil influencing governmental expenditures from the opportunities created by open government initiatives. These organizations stimulate the society engagement with the monitoring of the budgetary process, based on the production of indexes and reports, for instance, related to governmental transparency and social policies, respectively.

From this methodological design and addressing an open budget process focused on improvements in the quality of life, the interviewers asked the respondents to describe what they thought would be good measures of CSI and OBA. After completing the data collection process, it was conducted a validation procedure, by sending each interviewee the transcript of his or her interview for their assessment.

The selection of three budgetary experts from different organizations for each of the five groups was strategic in the sense that opinions were gathered from experts on all the stages of the budgetary process, from the development phase to the evaluation phase. The focus in this paper is content analysis, for it has the potential to maximise the extraction of knowledge from interview responses using open questions, and to integrate evidence from different levels in a structured framework (Bardin, 1977; Bryman, 2012).

The collected data was analysed focusing on the data classification into clusters. Then, based on these clusters, three different categories were identified: Measurement Forms (A); Complementary Issues (B); and Further Perspectives (C). See the content analysis framework in figure 1.

The NVIVO software was used for the content analysis. The results are presented in clusters of categories, linked with groups of interviewees, and highlighting their theoretical contribution. The Rapidminer program for data mining was also used, to explore and identify the priority clusters and their relationships. Finally, a net-map of the relationships between the groups, to find clusters, was designed using the Ucinet software. 


\section{FIGURE 1 CONTENT ANALYSIS FRAMEWORK}

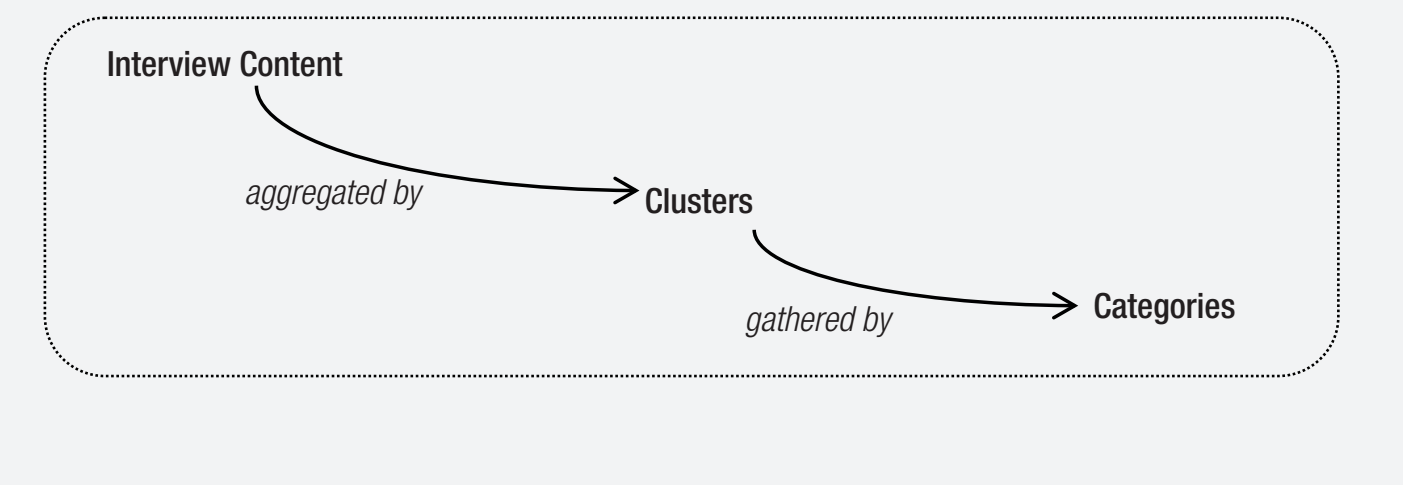

Source: Elaborated by the authors.

\section{RESULTS AND DISCUSSION}

First, we present the results of the content analyses. The clusters provide evidence on how to measure CSI and OBA. Clusters are identified by groups of respondents. Table 1 shows the clusters of Measurement Forms, which we discuss below.

\section{TABLE 1 MEASUREMENT FORMS}

\begin{tabular}{|c|c|c|c|c|c|c|c|c|}
\hline \multirow{2}{*}{ Clusters } & \multicolumn{2}{|c|}{ Related to } & \multicolumn{6}{|c|}{ 0ccurrences ${ }^{*}$} \\
\hline & OBA & CSI & NCC & GFA & SGE & PBR & CSO & Sum \\
\hline A01 - The number of civil society organisations & & $\sqrt{ }$ & 3 & 3 & 3 & 1 & 3 & 13 \\
\hline A02 - The presence of social councils and their components of operation & $\sqrt{ }$ & & 1 & 2 & 3 & 2 & 2 & 10 \\
\hline $\begin{array}{l}\text { A03 - The existence of specific elements of a government open data } \\
\text { process }\end{array}$ & $\sqrt{ }$ & & & & 2 & 2 & 2 & 6 \\
\hline $\begin{array}{l}\text { A04 — The occurrence of participatory budget characteristics in } \\
\text { public choices }\end{array}$ & $\sqrt{ }$ & & & 2 & 1 & & 1 & 4 \\
\hline A05 - The government's answerability to citizen questioning & $\sqrt{ }$ & & & & 2 & 1 & & 3 \\
\hline Sum & & & 4 & 7 & 11 & 6 & 8 & 36 \\
\hline
\end{tabular}

Source: Elaborated by the authors.

* NCC - National Congress consultants, GFA - government finance analysts, SGE - social government executives, PBR - public budget researchers, and CSO — civil society organisations. 
The respondents gave clear evidence that the number of Civil Society Organisations measures the level of CSI. The presence of social councils, open data systems, participatory budgeting and government answerability are all indicators of the level of OBA. Clusters A01 (13) and A02 (10) are crucial, because of the strong evidence given by all groups of interviewees, and these two clusters are associated with OBA and CSI respectively. Table 2 presents the clusters for the Complementary Issues category.

From the number of occurrences, we highlight clusters B01 and B02, which suggest that the accountability level together with the standardisation of transparency and participation can be used as indicators. Measuring of the level of OBA is not a simple process. The budgetary agenda is not clearly stated most of the time.

The OBI is an incomplete reference for determining the levels of open budget actions, because it concentrates the measurement effort on transparency aspects, missing components related to participation and accountability. Measure OBA in a proper manner, one needs to take into account open government practices and open budget principles. The federal government supports participatory action, such as the participation of legislative commissions.

The Brazilian CSI measurement can use the Brazilian civil organisation survey as a preference, which relates to non-Profit organisations, classified by legal nature, as social organisations, civil society organisations of public interest, and private national and foreign organisations. We anticipate that public policy will improve when the government collaborates more with civil society organisations. The implementation of the Brazilian Health System is good evidence of CSI.

\section{TABLE 2 COMPLEMENTARY ISSUES}

\begin{tabular}{|c|c|c|c|c|c|c|c|c|}
\hline \multirow[b]{2}{*}{ Clusters } & \multicolumn{2}{|c|}{ Related to } & \multicolumn{6}{|c|}{ 0ccurrences* } \\
\hline & OBA & CSI & NCC & GFA & SGE & PBR & cso & Sum \\
\hline $\begin{array}{l}\text { B01 - Determination of the accountability level associates to } \\
\text { the transparency and participation measurement }\end{array}$ & $\sqrt{ }$ & & 1 & 2 & 3 & 2 & 3 & 11 \\
\hline $\begin{array}{l}\text { B02 - The mechanism for measurement related to the Open } \\
\text { Budget Index is a good reference to infer the transparency level }\end{array}$ & $\sqrt{ }$ & & 1 & 2 & 1 & & 2 & 6 \\
\hline $\begin{array}{l}\text { B03 - The Brazilian municipal civil society organizations } \\
\text { relates to items of the IBGE FASFIL Survey }\end{array}$ & & $\sqrt{ }$ & & & & 2 & & 2 \\
\hline $\begin{array}{l}\text { B04 - The Brazilian municipal open budget connects with } \\
\text { items of the IBGE MUNIC Survey }\end{array}$ & $\sqrt{ }$ & & & & & 2 & & 2 \\
\hline B05 - The E-GOV initiatives associated with participation & $\sqrt{ }$ & & & 2 & & & & 2 \\
\hline $\begin{array}{l}\text { B06 - The Brazilian Health System, for instance, is an } \\
\text { evidence of social result related to the influences of civil society } \\
\text { organisations in the government decision-making process }\end{array}$ & & $\sqrt{ }$ & 1 & & 1 & & & 2 \\
\hline
\end{tabular}




\begin{tabular}{|c|c|c|c|c|c|c|c|c|}
\hline \multirow[b]{2}{*}{ Clusters } & \multicolumn{2}{|c|}{ Related to } & \multicolumn{6}{|c|}{ Occurrences* } \\
\hline & ОВА & CSI & NCC & GFA & SGE & PBR & cso & Sum \\
\hline $\begin{array}{l}\text { B07 - The activity of the civil society organisations indicates } \\
\text { the compliance with the influences of civil society }\end{array}$ & & $\sqrt{ }$ & 1 & & 1 & & & 2 \\
\hline $\begin{array}{l}\text { B08 - The Participatory Commission of Brazilian Parliament } \\
\text { supports political social demands of society }\end{array}$ & $\sqrt{ }$ & & 1 & & & 1 & & 2 \\
\hline B09 - The OBA measurement is complex & $\sqrt{ }$ & & & & & & 2 & 2 \\
\hline B10 - The OBA are themselves mutually integrated & $\sqrt{ }$ & & & & & 1 & & 1 \\
\hline $\begin{array}{l}\text { B11 - Civil society organisations collaborate more when they } \\
\text { do not receive resources from governments }\end{array}$ & & $\sqrt{ }$ & & & 1 & & & 1 \\
\hline $\begin{array}{l}\text { B12 - The participation initiatives are easier to execute in } \\
\text { local governments }\end{array}$ & $\sqrt{ }$ & & & & & 1 & & 1 \\
\hline B13 - The OBA affects the level of social progress & $\sqrt{ }$ & & 1 & & & & & 1 \\
\hline $\begin{array}{l}\text { B14 - The implementation of OBA considers the GIFT, Pefa, } \\
\text { and Inesc principles }\end{array}$ & $\sqrt{ }$ & & & & & & 1 & 1 \\
\hline Sum & & & 6 & 6 & 7 & 9 & 8 & 36 \\
\hline
\end{tabular}

Source: Elaborated by the authors.

${ }^{*}$ NCC - National Congress consultants, GFA - government finance analysts, SGE - social government executives, PBR - public budget researchers, and $\mathrm{CSO}-$ civil society organisations.

In the Further Perspectives category (see table 3), each of the fourteen clusters has less than five occurrences. Nevertheless, all of them are crucial because they offer good suggestions, either to improve government actions or to support new studies.

\section{TABLE 3 FURTHER PERSPECTIVES}

\begin{tabular}{|c|c|c|c|c|c|c|c|c|}
\hline \multirow{2}{*}{ Clusters } & \multicolumn{2}{|c|}{ Related to } & \multicolumn{6}{|c|}{ 0ccurrences* } \\
\hline & OBA & CSI & NCC & GFA & SGE & PBR & CSO & Sum \\
\hline $\begin{array}{l}\text { C01 - The Brazilian governments may develop more channels } \\
\text { to interact with collaborative stakeholders }\end{array}$ & & $\sqrt{ }$ & 2 & 1 & & & 1 & 4 \\
\hline $\begin{array}{l}\text { C02 - The budgetary education initiative may support more } \\
\text { budget participation initiatives }\end{array}$ & $\sqrt{ }$ & & 1 & & 1 & 1 & 1 & 4 \\
\hline
\end{tabular}




\begin{tabular}{|c|c|c|c|c|c|c|c|c|}
\hline \multirow{2}{*}{ Clusters } & \multicolumn{2}{|c|}{ Related to } & \multicolumn{6}{|c|}{ Occurrences* } \\
\hline & $\mathrm{OBA}$ & CSI & NCC & GFA & SGE & PBR & cso & Sum \\
\hline $\begin{array}{l}\text { CO3 - The budget allocation laws (amendments) enacted in } \\
\text { response to civil society organisations' interests may indicate } \\
\text { who is involved in the budgetary process }\end{array}$ & $\sqrt{ }$ & & 1 & 1 & & 1 & & 3 \\
\hline $\begin{array}{l}\text { C04 - The government stakeholders may believe more in the } \\
\text { power of collaborative stakeholders to influence social results }\end{array}$ & & $\sqrt{ }$ & 1 & & & & 1 & 2 \\
\hline $\begin{array}{l}\text { C05 - The Brazilian audit tribunals may be more open- } \\
\text { minded to accept innovative actions with an accountability } \\
\text { perspective }\end{array}$ & $\sqrt{ }$ & & 1 & & & 1 & & 2 \\
\hline $\begin{array}{l}\text { CO6 - The social results may stimulate a virtuous circle from } \\
\text { OBA }\end{array}$ & $\sqrt{ }$ & & 1 & & & 1 & & 2 \\
\hline $\begin{array}{l}\text { C07 - The Brazilian budget actions may not have actions with } \\
\text { unclear descriptions }\end{array}$ & $\sqrt{ }$ & & 1 & 1 & & & & 2 \\
\hline $\begin{array}{l}\text { C08 - The Brazil transparency level may be more useful in } \\
\text { practical terms }\end{array}$ & $\sqrt{ }$ & & 1 & & & & 1 & 2 \\
\hline $\begin{array}{l}\text { C09 - The Open Budget Index may consider elements of } \\
\text { participation in its measurement mechanisms }\end{array}$ & $\sqrt{ }$ & & & & & & 2 & 2 \\
\hline $\begin{array}{l}\text { C10 - The data from IBGE PNAD surveys may relate to the } \\
\text { Brazilian municipal level of social indexes }\end{array}$ & $\sqrt{ }$ & & & & & 1 & & 1 \\
\hline $\begin{array}{l}\text { C11 - The participation in budget formulation may guarantee } \\
\text { the corresponding participation in budget evaluation }\end{array}$ & $\sqrt{ }$ & & & 1 & & & & 1 \\
\hline $\begin{array}{l}\text { C12 - The accountability initiatives may be better developed } \\
\text { at all Brazilian government levels }\end{array}$ & $\sqrt{ }$ & & 1 & & & & & 1 \\
\hline $\begin{array}{l}\text { C13 - The budgetary articles in the media may indicate the } \\
\text { level of openness actions }\end{array}$ & $\sqrt{ }$ & & 1 & & & & & 1 \\
\hline $\begin{array}{l}\text { C14 - The participation may avoid restrictions regarding } \\
\text { budgetary resources }\end{array}$ & $\sqrt{ }$ & & & & & & 1 & 1 \\
\hline Sum & & & 11 & 4 & 1 & 5 & 7 & 28 \\
\hline
\end{tabular}

Source: Elaborated by the authors.

${ }^{*}$ NCC - National Congress consultants, GFA - government finance analysts, SGE - social government executives, PBR - public budget researchers, and CSO - civil society organisations. 
For example, it is important that governments create channels to interact with collaborative stakeholders. This includes evaluation processes, using clear specifications of budget actions, from transparency to innovative accountability measures, without limiting them to small amounts of resources. Similarly, the government needs to prioritise budget education, and to consider the power of collaborative stakeholders to have a positive influence on the decision-making process. The legislative budget allocations and articles in the news media provide additional evidence of CSI.

In addition, the OBA is associated with social progress, which can be measured using selected items from municipal surveys. The adoption of OBA ought to promote a virtuous cycle of social progress. For instance, the existence of community participation in municipal health and education councils should be crucial to determinate the OBA level.

We emphasize that the data for each category of evidence was obtained from a different group of interviewees (figure 2). The strongest contribution to Measurement Forms came from social government executives (11), public budget researchers (9) and National Congress consultants (11). One curiosity is that we did not find evidence from social government executives for Further Perspectives. However, every group of interviewees contributed to a similar number of clusters, with an average of 20.

\section{FIGURE 2 OCCURRENCES IN GROUPS OF INTERVIEWERS BY CATEGORIES}

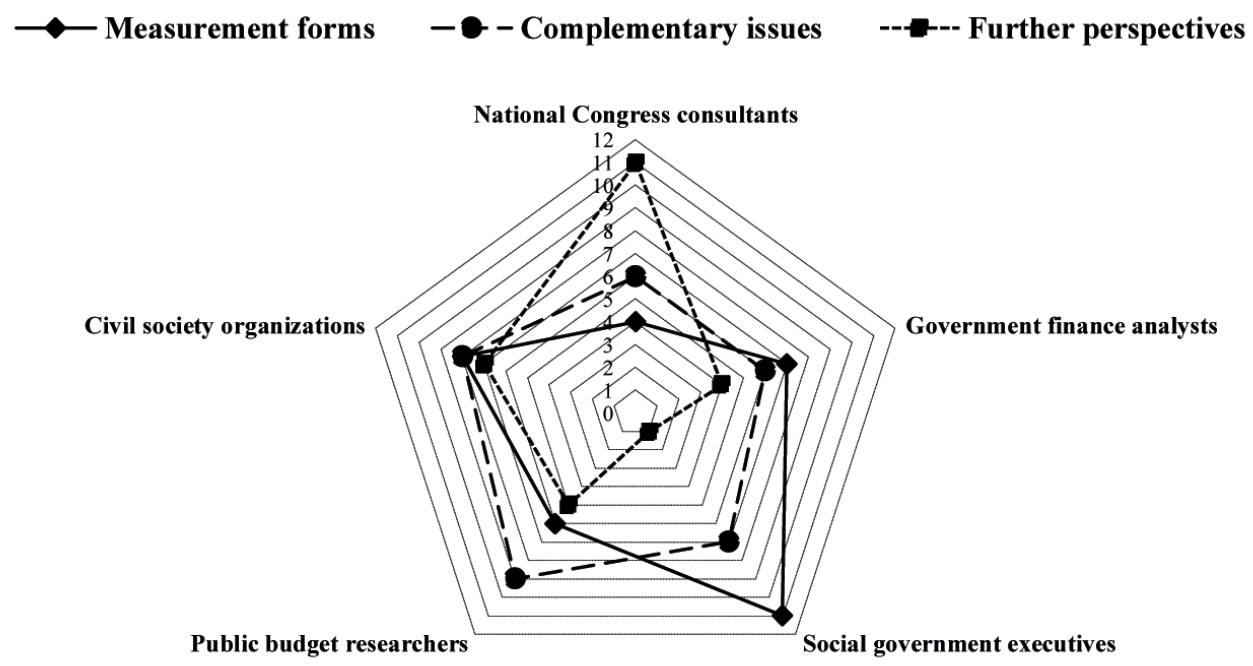

Source: Elaborated by the authors.

Next, from the analysis of the net-map (figure 3), we note the relevance of clusters A01, B01, and A02. Because all groups of interviewees refer to these three clusters, they stayed in a core (central) position in the net-map of relationships between clusters and social groups, based on the nearest Euclidean distance. 


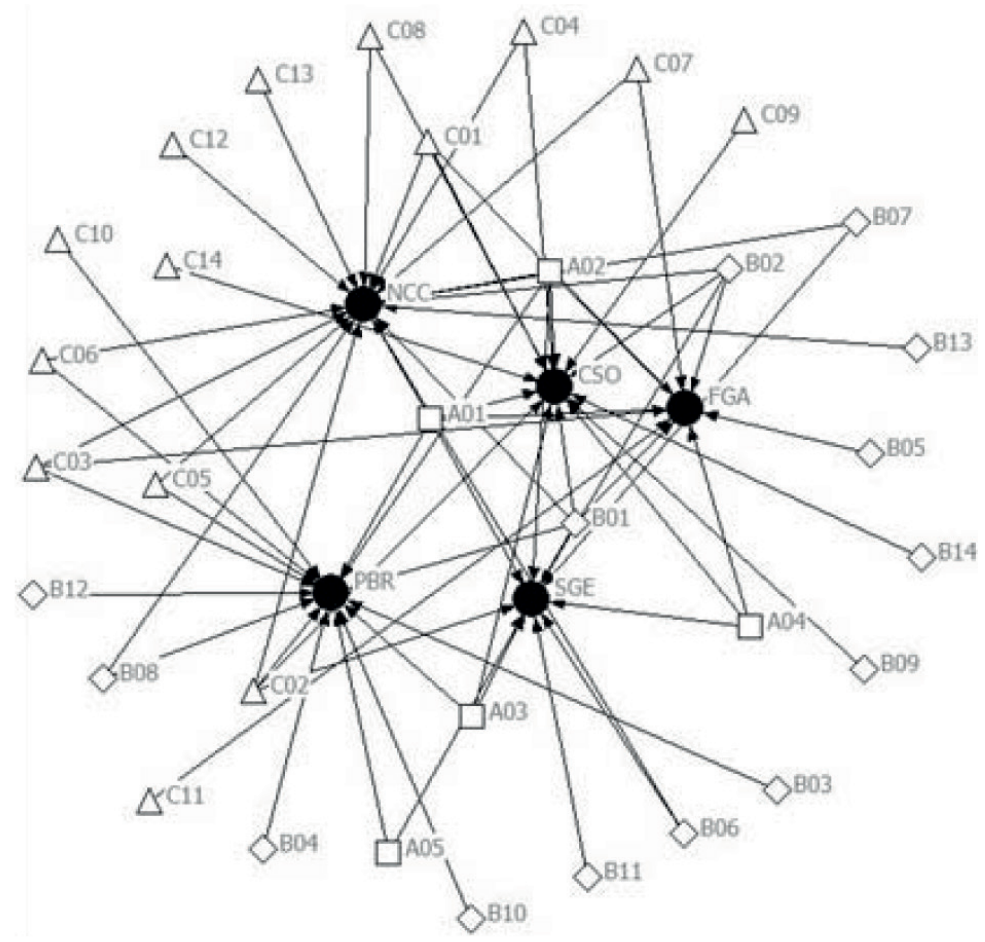

Source: Elaborated by the authors.

* Social Groups: NCC - National Congress consultants, GFA — government finance analysts, SGE - social government executives, PBR - public budget researchers, and CSO - civil society organisations.

** See cluster codes and their descriptions in tables 1 to 3 .

The analysis of the interviews produced evidence on how to measure CSI and OBA, their complementary issues and further perspectives. The clusters grouped the evidence, gathered into categories. Clusters A01, B01, and A02 have the highest values.

\section{FINAL CONSIDERATIONS}

This article provides an examination of the core elements of open budgets as determining factors of social development. It is based on concepts of public administration, such as governance, social science, public budgets, and stakeholder participation. Theoretical considerations of collaborative stakeholders and open budget approaches indicate a need to extend the literature by identifying innovative ways to measure CSI and OBA.

The evidence produced from content analyses of the interviews is relevant, and the following points are considered the core results after the use of data mining and net mapping techniques. While the number of civil society organisations is the determining factor in the measurement of the level of CSI, the presence of social councils, open data, participatory budgeting, and government answerability indicates the level of OBA. The level of accountability, together with the standardisation 
of transparency and participation, provide further insights. The Open Budget Index is a good starting point for the measurement of levels of transparency.

We highlight some practical recommendations for governments. Governments should create channels to interact with collaborative stakeholders, use clear specifications of budget actions, prioritise budget education and consider the power of collaborative stakeholders have a positive influence on the decision-making process.

Moreover, we observe that different social groups contribute more in various categories. Clusters A01 (the number of civil society organisations), B01 (measuring the level of accountability associated with transparency and participation), and A02 (the presence of social councils and their operational components) are identified, together with the relationships between social groups.

Therefore, the measurement of CSI (A01) and OBA (B01 and A02) must include these clusters, because of their respective associations. This evidence of CSI and OBA is associated with the premises of good governance, such as public engagement and a democratic environment.

Altogether, to help explain social development, this paper proposes ways to measure CSI and OBA. Based on this evidence, further quantitative studies could contribute to extending the theory of governance, compensating for the lack of consideration given to the consequences of open budget that were mentioned by Khagram and collaborators (2013).

This development of effective approaches to measuring elements of open budgets focuses on the gaps in the literature identified by Ling and Roberts (2014). At the same time, complementary qualitative investigations are needed to explore the functions of CSI and OBA more fully. We believe that the governments could use the empirical findings of such studies to improve governance outcomes.

Therefore, based on the results of this study, we hope that the influences of stakeholder cooperation and firmer actions on open budgets can be measured and included in more sophisticated approaches to governance. In this line of thinking, the integration of collaborative stakeholder influence with open budget actions is crucial in order to achieve social progress. For example, the open budget model could be applied to check the consequences of social development, using statistical tests.

From the evidence of this work on further perspectives, we identify some important issues that need to be prioritized on the research agenda:

- Which actions improve the interaction between government and collaborative stakeholders?

- How can budgetary education support participation in budgetary issues?

- Which have stakeholders a legal right to be involved in the budgetary process according to the budget allocation laws (as amended)?

- Why do many government stakeholders not consider the power of collaborative stakeholders to influence social results?

- Why are Brazilian audit tribunals not open-minded about accepting innovative action from an accountability perspective?

- Do social outcomes stimulate a virtuous circle from open budgets?

Finally, although there needs to be further research on the open budget approach, we hope that this empirical paper provides some critical insights into the public administration and development fields. Unfortunately, poor social conditions remain a great problem throughout the world, so studies of social progress are always welcome. 


\section{REFERENCES}

ABREU, Welles M. Orçamento público. Brasília, DF: Enap, 2013.

ABREU, Welles M.; GOMES, Ricardo C. Do open budget institutional changes improve social development? Contabilidade, Gestão e Governança, v. 19, n. 3, p. 422-439, 2016.

ABREU, Welles M.; GOMES, Ricardo C. The Brazilian public budget and the emancipatory perspective: is there any empirical evidence supporting this approach? Rev. Adm. Pública, Rio de Janeiro, 47, n. 2, p. 515-540, Mar./Apr. 2013.

ACKERMAN, John. Co-governance for accountability: beyond 'exit' and 'voice'. World Development, v. 32, n. 3, p. 447-463, 2004.

ADADEVOH, Eyram A. New wine in new wine skins: the anti-corruption framework of Ghana. The Journal of World Energy Law \& Business, v. 7, issue 3, p. 202-219, June 2014.

ALMEIDA, Rafael A. Gestão democrática na formatação de políticas públicas. 2015. 201f. Thesis (doctor degree) - Instituto de Economia, Programa de Pós-Graduação em Políticas Públicas, Estratégias e Desenvolvimento, Universidade Federal do Rio de Janeiro, Rio de Janeiro, 2014.

ALT, James E.; LOWRY, Robert C. Transparency and accountability: empirical results for U.S. states. Journal of Theoretical Politics, v. 22, n. 4, p. 379-406, 2010.

ANSELL, Chris; GASH, Alison. Collaborative governance in theory and practice. Journal of Public Administration Research and Theory, v. 18, n. 4, p. 543-571, 2008.

ANSELL, Chris; GASH, Alison. Collaborative platforms as a governance strategy. Journal of Public Administration Research and Theory, v. 28, n. 1, p. 16-32, Jan. 2018.

ARMSTRONG, Kenneth A. Inclusive governance? Civil society and the open method of co-ordination. In: SMISMANS, Stijn (Ed.). Civil society and legitimate European governance. Cheltenham: Edward Elgar, 2006. p. 42-67.

BARDIN, Laurence. Análise de conteúdo. Lisbon: Edições 70, 1977.
BOAZ, Annette; NUTLEY, Sandra. Evidence-based policy and practice. London: Routledge, 2003.

BOULDING, Carew; WAMPLER, Brian. Voice, votes, and resources: evaluating the effect of participatory democracy on well-being. World Development, v. 38, n. 1, p. 125-135, 2010.

BOVAIRD, Tony. Public governance: balancing stakeholder power in a network society. International Review of Administrative Sciences, v. 71, n. 2, p. 217 228, 2005.

BROWN, William A. Inclusive governance practices in nonprofit organizations and implications for practice. Nonprofit Management and Leadership, v. 12 , n. 4, p. $369-385,2002$.

BRYMAN, Alan. Social research methods. Bristol: Oxford University Press, 2012.

BURGE, Richard. Final report learning from DFID's governance and transparency fund (GTF): tools, methods and approaches. Unpublished report. TripleLine/KPMG, June 2010.

CRESWELL, John W. Research design: qualitative, quantitative, and mixed methods approaches. Thousand Oaks: Sage, 2013.

DAVIS, Gloria. A history of the social development network in The World Bank, 1973-2003. Washington, DC: The World Bank, 2004.

DE RENZIO, Paolo; GOMEZ, Pamela; SHEPPARD, James. Budget transparency and development in resource-dependent countries. International Social Science Journal, v. 57, n. 1, p. 57-69, 2009.

DE RENZIO, Paolo; MASUD, Harika. Measuring and promoting budget transparency: the open budget index as a research and advocacy tool. Governance, v. 24, n. 3, p. 607-616, 2011.

DE RENZIO, Paolo; WEHNER, Joachim. The impacts of fiscal openness: a review of the evidence. The World Bank Research Observer, v. 32, issue 2, p. 185-210, 1 Aug. 2017.

DENHARDT, Janet V.; DENHARDT, Robert B. The new public service: serving, not steering. Armonk: M. E. Sharpe, 2007.

DFID. Department for International Development. Governance, development and democratic politics. Londres: Department for International Development, 2006. 
EMERSON, Kirk; NABATCHI, Tina; BALOGH, Stephen. An integrative framework for collaborative governance. Journal of Public Administration Research and Theory, v. 22, n. 1, p. 1-29, 2012.

FREEMAN, Robert E. Strategic management: a stakeholder approach. Massachusetts: Pitman, 1984.

FRIIS-HANSEN, Esbern; COLD-RAVNKILDE, Signe M. Social accountability mechanisms and access to public service delivery in rural Africa. Copenhagen: DIIS Reports, Danish Institute for International Studies, 2013.

FUNG, Archon. Varieties of participation in complex governance. Public Administration Review, v. 66, n. s1, p. 66-75, 2006.

FUNG, Archon; WRIGHT, Erik O. Deepening democracy: institutional innovations in empowered participatory governance. Brooklyn: Verso, 2003.

GAVENTA, John; MCGEE, Rosemary. The impact of transparency and accountability initiatives. Development Policy Review, v. 31, n. s1, p. s3-s28, 2013.

GOETZ, Anne M.; JENKINS, Rob. Hybrid forms of accountability: citizen engagement in institutions of public-sector oversight in India. Public Management Review, v. 3, n. 3, p. 363-383, 2001.

GOMES, Ricardo C.; GOMES, Luciana O. M. Who is supposed to be regarded as a stakeholder for public organizations in developing countries? Public Management Review, v. 10, n. 2, p. 263-275, mar. 2008.

GOMES, Ricardo C.; LIDDLE, Joyce; GOMES, Luciana O. M. A five-sided model of stakeholder influence: a cross-national analysis of decision making in local government. Public Management Review, v. 12, n. 5, p. 701-724, 2010.

IBP. Annual report 2008-09: open budget initiative. Washington: International Budget Partnership, 2014.

JINGUANG, Hu; XIANYONG, Zhang. On the value and path of open budget. Nankai Journal (Philosophy, Literature and Social Science Edition), v. 2, p. 72-83, 2011.

JUSTICE, Jonathan B.; MCNUTT, John G. Social capital, e-government, and fiscal transparency in the states. Public Integrity, v. 16, n. 1, p. 5-24, 2013.
KASYMOVA, Jyldyz T.; SCHACHTER, Hindy L. Bringing participatory tools to a different level. Public Performance \& Management Review, v. 37, n. 3, p. 441-464, 2014.

KEIJZERS, Gerard. Creating sustainable directions: evolving stakeholder approach in seven multinationals. The Journal of Corporate Citizenship, n. 10, p. 79-89, 2003.

KHAGRAM, Sanjeev; ALI, Salim. Transnational transformations: from government-centric interstate regimes to cross-sectoral multi-level networks of global governance? In: LARK, Jacob et al. (Ed.). Globalization and environmental governance: toward a new political economy of sustainability. London: Routledge, 2008. p. 132-162.

KHAGRAM, Sanjeev; FUNG, Archon; DE RENZIO, Paolo. Open budgets: the political economy of transparency, participation, and accountability. Washington, DC: Brookings Institution Press, 2013.

KOONTZ, Tomas M. We finished the plan, so now what? Impacts of collaborative stakeholder participation on land use policy. Policy Studies Journal, v. 33, n. 3, p. 459-481, 2005.

LEE, Nick; LINGS, Ian. Doing business research: a guide to theory and practice. Thousand Oaks: Sage, 2008.

LING, Cristina; ROBERTS, Dawn K. Evidence of development impact from institutional change: a review of the evidence on open budgeting. Washington, DC: World Bank Group, 2014. p. 32.

MANSURI, Ghazala; RAO, Vijayendra. Communitybased and-driven development: a critical review. The World Bank Research Observer, v. 19, n. 1, p. 1-39, 2004.

MEIJER, Albert. Understanding modern transparency. International Review of Administrative Sciences, v. 75, n. 2, p. 255-269, 2009.

MEIJER, Albert. Understanding the complex dynamics of transparency. Public Administration Review, v. 73, n. 3, p. 429-439, 2013.

MITCHELL, Ronald K.; AGLE, Bradley R.; WOOD, Donna J. Toward a theory of stakeholder identification and salience: defining the principle of who and what really counts. Academy of Management Review, v. 22, n. 4, p. 853-886, 1997. 
NOWAK, Robert. Transparency and good governance in transition economies. Switzerland: United Nations Economic Commission for Europe, 2000. p. 10.

O'TOOLE, Laurence J.; MEIER, Kenneth J. Modeling the impact of public management: implications of structural context. Journal of Public Administration Research and Theory, v. 9, n. 4, p. 505-526, 1999.

OECD. Organisation for Economic Co-Operation and Development. OECD best practices for budget transparency. Paris: OECD, 2002.

SARKER, Abu E.; HASSAN, Mostafa K. Civic engagement and public accountability: an analysis with particular reference to developing countries. Public Administration and Management, v. 15, n. 2, p. 381, 2010.

SAVAGE, Grant T. et al. Strategies for assessing and managing organizational stakeholders. Academy of Management Executive, v. 5, n. 2, p. 61-75, 1991.

SHAH, Anwar. Participatory budgeting. Washington, DC: World Bank Group, 2007.

SIAU, Keng; LONG, Yuan. Using social development lenses to understand e-government development. Journal of Global Information Management (JGIM), v. 14, n. 1, p. 47-62, 2006.

SILVERMAN, David. Qualitative research. Thousand Oaks: Sage, 2010.

STREECK, Wolfgang; THELEN, Kathleen. Beyond continuity: institutional change in advanced political economies. Oxford: Oxford University Press, 2005.

SVENDSEN, Ann. The stakeholder strategy: profiting from collaborative business relationships. Oakland: Berrett-Koehler, 1998.
TANAKA, Susan. Engaging the public in national budgeting. OECD Journal on Budgeting, v. 7, n. 2, p. 139-177, 2007.

TISNÉ, Martin. Transparency, participation and accountability: definitions. Nota conceitual não publicada para Transparency and Accountability Initiative, 2010.

WAMPLER, Brian. Participation, transparency and accountability: innovations in South Korea, Brazil, and the Philippines. GIFT, 2012. Available at: <www.fiscaltransparency.net/resourcesfiles/ files/20151009134.pdf>. Accessed on: 28 Dec. 2015.

WORLD BANK. Social development. Available at: <www.worldbank.org/en/topic/socialdevelopment/ overview>. Accessed on: 13 Dec. 2014.

YILMAZ, Serdar; BERIS, Yakup; SERRANOBERTHET, Rodrigo. Linking local government discretion and accountability in decentralization. Development Policy Review, v. 28, n. 3, p. 259-293, 2010.

YOU, Jong-Sung; LEE, Wonhee. A mutually reinforcing loop: budget transparency and participation in South Korea. In: KHAGRAM, Sanjeev; FUNG, Archon; DE RENZIO, Paolo (Ed.). Open budgets: the political economy of transparency, participation, and accountability. Washington, DC: Brookings Institution Press, 2013. p. 105-129.

ZUCCOLOTTO, Robson. Fatores determinantes da transparência do ciclo orçamentário estendido: evidências nos estados brasileiros. 2014. $202 \mathrm{f}$. Thesis (doctor degree in science) - Faculdade de Economia, Administração e Contabilidade, Universidade de São Paulo, São Paulo, 2014.

\section{Welles Matias de Abreu}

Doctorate degree in public administration from University of Brasilia (UnB) and works as analyst of planning and budgeting at Brazilian Federal Budget Office. E-mail: wellesmatias@gmail.com.

\section{Ricardo Correa Gomes}

Post-doctoral in the University State Georgia (USA), has doctorate degree in Public Administration from Aston University (UK), and works as associate professor at University of Brasília (UnB). E-mail: rgomes@unb.br. 